\title{
MEZCAL AND MEXICANNESS: THE SYMBOLIC AND SOCIAL CONNOTATIONS OF DRINKING IN OAXACA ${ }^{1}$
}

\author{
Toomas Gross
}

\begin{abstract}
This article discusses the symbolic and social connotations of mezcal and its consumption in the rural communities of Oaxaca in Southern Mexico. Mezcal, a traditional drink in this region, is a distilled alcoholic beverage made from a particular type of agave called maguey. Based on the author's intermittent fieldwork in the indigenous Zapotec villages of Oaxaca since the late 1990s, the article will scrutinise the local discourse on mezcal, the meanings attached to the drink, and the consumption of mezcal in ritual and social contexts. As the article will demonstrate, an anthropological perspective on mezcal enables us to approach the drink not simply as an alcoholic beverage among many others, but as a very specific cultural construct that is part of a distinct drinking culture. Consuming mezcal in rural Oaxaca is a social act: the collective drinking of mezcal contributes to a sense of community and belonging. Mezcal also serves as a summarising symbol, to use Ortner's term, which metaphorically captures the character and essence of being a serrano (highlander). On the other hand, drinking mezcal can also serve as a marker of social divisions and group boundaries. Consumption and non-consumption of mezcal largely coincides with the boundaries between social groups based either on gender or on religion. The article will close with a brief glimpse at recent state level endeavours to construct mezcal as Mexico's national drink, often building on its local meanings.
\end{abstract}

Keywords: community, drinking, mezcal, Mexico, Oaxaca, symbol

\section{INTRODUCTION}

This article discusses the meanings of mezcal and its consumption in southern Mexico, with particular ethnographic attention on the indigenous Zapotec communities in the state of Oaxaca. In these communities, mezcal - a distilled alcoholic beverage made from a particular type of agave called maguey - is a traditional drink consumed widely on both mundane and ritual occasions. The article builds on the author's extended fieldwork in the region called the Sierra Juárez since the late $1990 \mathrm{~s}$, most recently in $2012 .^{2}$

The main aim of the article is to demonstrate that an anthropological perspective on mezcal enables us to approach the drink not simply as an 
alcoholic beverage among many others, but as a very specific cultural and social construct. I will particularly focus on the symbolic and social dimensions of mezcal. As I demonstrate, in many respects the drink functions as a metaphor. Mezcal is generally talked about with pride; it is personified and endowed with nearly magical powers. The drink is considered to capture the essence of the local population and as such it constitutes what Sherry Ortner (1973) has called a 'summarising symbol'. But consuming mezcal is also a social act. As anthropologists have eloquently demonstrated in multiple contexts, there is much more to consuming food and drink than the mere physiological satisfaction of hunger and thirst. ${ }^{3}$ The mainly collective drinking of mezcal in rural Oaxaca has implications for social solidarity - its consumption often creates a strong sense of community. On the other hand, drinking mezcal can also serve as a marker of social divisions and group boundaries. Consumption and nonconsumption of mezcal in Oaxacan villages largely coincides with the boundaries between social groups based either on gender (men vs. women) or religion (Catholics vs. Protestants). Thus the fact of consuming (or not consuming) mezcal can function as a shortcut to demarcating and reinforcing the boundaries between these groups.

In the discussion that follows I will put these two main analytical concerns - the symbolic and social connotations of mezcal - into a somewhat broader anthropological and national context. After a brief presentation of the anthropology of drinking cultures as a rather recent subfield within the discipline, I will introduce mezcal as a drink in the context of the drinking culture of Mexico in general. Mezcal belongs to a family of three endemic Mexican alcoholic beverages, and its cultural and social meanings that I will discuss thereafter should be understood in this framework. The article will close with a brief glimpse at recent state level endeavours to construct mezcal as Mexico's national drink. The state-sponsored promotion of mezcal's wider appeal builds on the local metaphorical discourse on the drink, central to which are the notions of authenticity, essence, character, and Mexicanness.

\section{THE ANTHROPOLOGY OF DRINKING CULTURES}

The study of food and eating has a long history in anthropology, going back at least to the work of Garrick Mallery (1888) and William Robertson Smith (1889), although it is in the past few decades that the anthropology of food has gained true momentum as a sub-discipline (Mintz \& Du Bois 2002). Theoretically solid and ethnographically informed anthropological interest in drinking (with a particular focus on alcohol) is much more recent, however. This may 
sound surprising since alcohol production has a long history and is an essential part of culturally constituted social relations. Yet it is only since the 1960 s that anthropological perspectives have been more prominently represented in the growing field of alcohol studies and that ethnographic descriptions of drinking patterns among various world populations have proliferated (Heath 1987: 101; Dietler 2006: 230). ${ }^{4}$

The growing interest in alcohol and drinking has been fuelled by anthropologists' realisation that consuming alcohol correlates with cultural, religious, and social identities, as well as with ethnicity, gender, and class. A myriad of studies have by now addressed the great variation of beliefs, practices, and attitudes towards drinking across and within cultures (e.g. Marshall 1979; Barrows \& Room 1991; Pittman \& Raskin White 1991; Gefou-Madianou 1992; Heath 1995, 2000; Garine \& Garine 2001). In most of these accounts, the social construction of drinking provides anthropologists with an analytical tool with which to approach different socio-cultural groups and to compare them. The culturally constructed nature of drinking behaviour is implicit in such by now commonly used notions as drinking cultures (Wilson 2005), drinking patterns (Pittman \& Raskin White 1991; Grant \& Litvak 1997), and drinking styles (Heath 2000).

The anthropological perspective on drinking is rather distinct. In most other disciplines that focus on alcohol and drinking, the main aspect of study tends to be alcoholism - in other words, the abuse of drink. Anthropologists, on the other hand, generally focus on those individuals who drink moderately (Heath 1987: 105). As paradoxical as it may sound, anthropology often emphasises the 'benefits' of drinking and mainly focuses on how drinking is 'positively' embedded in everyday ways of life (ibid.: 115). Heath (2000), for example, describes a variety of 'normal' drinking occasions that exist around the world and the many ways that people think about or use alcohol as an integral and 'beneficial' part of their culture. The tendency to focus on the 'benefits' of drinking in anthropology is, of course, not exclusive of other approaches, especially in the field of medical anthropology. But a prevailing emphasis has nevertheless been on 'constructive drinking', to use Mary Douglas's (1987) term, rather than on the harmful and destructive effects of alcohol abuse. Not everyone applauds such approaches in anthropology. In a well-known critique of anthropological perspectives on alcohol, Room (1984) accuses anthropologists of 'problem deflation' when overlooking or diminishing the alcohol abuse and its implications (see also Marshall 1990). In the discussion that follows, my attention will mainly be on the symbolically and socially 'constructive' aspects of consuming mezcal, but I am aware of the problems embedded in such one-sided analytical perspective. As I will demonstrate, the 'constructive approach' to drinking 
mezcal is not shared by all villagers, and some social groups - Protestants in particular - very explicitly highlight the harmful effects of consuming alcohol.

\section{THE DRINKING CULTURE OF MEXICO}

The case of Mexico is somewhat distinct when it comes to the anthropology of drinking and alcohol. Not surprisingly, the body of anthropological studies of Mexican food is ample and their common analytical denominator tends to be linking cuisine strongly to Mexican national or regional identities. ElvridgeThomas (2009: 59) even claims that "we, in Mexico, feel emotionally more connected with our country while tasting a taco or eating quesadillas with salsa picante, than when singing the national anthem". But unlike in many other ethnographic contexts, in Mexico drinking and alcohol have also received considerable social scientific attention. The interest dates back at least to the 1930s and the early studies were dominated by the focus on alcohol abuse and its destructive effects on the country's indigenous population (e.g. Mendieta y Núñez 1939; Bunzel 1940; Rojas Gonzalez 1942). ${ }^{5}$ Consumption of pulque ${ }^{6}$ in particular was accused of contributing to widespread alcoholism in indigenous Mexico. In post-WWII era, anthropological studies of alcohol and drinking in Mexico - in both pre-colonial (e.g. Bruman 2000), colonial (e.g. Taylor 1979; Scardaville 1980), and contemporary contexts (e.g. Kearney 1970, 1971; Dennis 1975; DeWalt 1979; Menéndez 1991; Eber 1995; Avila Palafox 2001) - have proliferated rapidly. In a recent account entitled Intoxicated Identities, Mitchell (2004) even seeks to demonstrate, provocatively, that Mexican culture reinforces heavy drinking. Such essentialist argument is, of course, highly problematic, but finds resonance with the Protestants' critique of Catholicism and Catholics in rural Oaxaca. As I will argue below, Protestants often claim that Catholic fiestas and the festive veneration of saints reinforce drinking.

Three 'archetypal' drinks are endemic to the Mexican drinking culture. All of them - tequila, pulque, and mezcal - are made from the agave plant locally known as maguey. The maguey is considered to have been one of the most sacred plants in pre-Hispanic Mexico; it had a privileged position in various religious rituals, mythology, and economy (Blomberg 2000: 17). From an anthropological perspective all three drinks have a significant symbolic dimension, and have been tightly linked to national and regional collective identities. Tequila, internationally the best known of the three beverages and made exclusively from the so-called blue agave, became a veritable national symbol of Mexico abroad in the second half of the twentieth century. ${ }^{7}$ This was so partly because tequila fit the image of modern Mexico better than pulque and mezcal 
(Gaytán 2007: 18). Pulque was 'too Indian' and associated too closely with the urban poor. Mezcal, although consumed by creoles and mestizos during the early colonial period, also became marked mainly as an Indian product, since its production is concentrated in Oaxaca, the most indigenous state of Mexico. Produced predominantly in the relatively well-off state of Jalisco, tequila, in contrast, was the least associated with Indians and the lower classes, and thus embodied - much more conveniently than pulque or mezcal - the virtues of the 20th century national discourse of modernity, growth, unity, and Mexicanness (Gaytán 2007: 18-19).

Despite that, many scholars still refer to pulque, a beverage made by fermenting the sap of certain types of maguey, as the true bebida nacional ('national drink') in the 20th-century Mexico. It has often been considered to be more 'quintessentially Mexican' than tequila (e.g. Díaz Montes 1982; Guerrero Guerrero 1985). ${ }^{8}$ Unlike tequila, pulque's history extends far back into the pre-colonial era, when it was considered sacred and consumed only by certain classes of people (mainly priests, nobles, and the elderly). After the Spanish Conquest, the drink became secular and its consumption increased rapidly and widely (Taylor 1979: 35). Nevertheless, drinking pulque remained an exclusively Indian enterprise and, for Spaniards, a sign of Indians' backwardness (Gaytán 2007: 3-4). ${ }^{9}$ Anthropologically, the most interesting era in the history of pulque was the first half of the 20th century, immediately after the Mexican Revolution, when in some social circles attempts were made to consciously modify the drink's national image and symbolic connotations. This, as I will demonstrate below, bears certain similarity with contemporary state-driven attempts to promote and internationalise mezcal. As Wright (2009) argues, during Mexico's nation-building period in 1920-46, pulque's image was purposefully re-invented in order to facilitate its recognition - both home and abroad - as the country's national drink. Owing both to its pre-colonial Aztec roots and its quotidian consumption by plebeian communities, pulque constituted for many an appropriate metaphor for la Mexicanidad ('Mexicanness') and for the participatory and inclusive Mexican national identity (Wright 2009: 3). Its promotion as a national symbol was strongly backed by some prominent figures in the Mexican cultural elite. ${ }^{10}$ Borrowing from Hobsbawm \& Ranger (1983), Wright (2009: 4) argues that in reality such essentialised constructions constituted an 'invention of tradition'. Since the middle of the 20th century, however, the popularity of pulque has steadily declined (Ramírez et al. 2004). ${ }^{11}$

Mezcal could be considered the 'minor brother' in the family of Mexican agave drinks. For most of the 20th century, mezcal did not possess the metaphorical power and nationwide symbolic appeal of tequila and pulque. On the contrary, until recent years, mezcal as a drink has been internationally relatively un- 
known and its consumption has been far more endemic to Southern Mexico. Its mainly local appeal does not mean, however, that mezcal lacks potent symbolic and social connotations in the regional context, as I will demonstrate in the next two sections.

Mezcal production originated in colonial times. Although some scholars (e.g. Serra \& Carlos 2010) situate its origin in the pre-colonial era, a more common view is that mezcal is essentially a Spanish invention (Gaytán 2007: 1). The word 'mezcal' itself most probably comes from the Nahuatl word mexcalli, which is a combination of the words metl and ixcalli, and literally means 'oven cooked agave' (Montero 2011: 106). Mezcal is traditionally made from the cooked heart of certain agave plants, mainly of Agave espadin. ${ }^{12}$ While tequila is generally produced in factories, most if not all good mezcals are handmade by smallscale producers in the so-called fábricas or palenques, often using methods and techniques that have been practiced for centuries (Bautista \& Terán Melchor 2008: 118). ${ }^{13}$ To be truly considered mezcal, the liquor must come from certain areas, be produced from certain types of maguey, and by using only certain acknowledged production techniques (Montero 2011: 106). ${ }^{14}$

\section{MEZCAL AS A SUMMARISING SYMBOL}

I will now turn to scrutinising the symbolic and social connotations attached to mezcal in the Zapotec villages of Oaxaca. A brief overview of the broader ethnographic context is first in order, however, as it enables the reader to better capture the cultural idiosyncrasies of rural Oaxaca and the region of the Sierra Juárez, where I have done intermittent fieldwork since 1998, altogether for approximately 21 months (see endnote 2).

Oaxaca, the 'home of mezcal', is ethnically the most diverse of Mexico's 31 states. Its indigenous population, constituting nearly half of the state's total and belonging to sixteen different linguistic groups, amounts to approximately 18 percent of the total indigenous population of Mexico. Geographically, the state of Oaxaca is divided into eight regions. One of these, the northern mountainous region of the Sierra Norte, comprises an area called the Sierra Juárez. The population of the Sierra Juárez is mainly Zapotec, but Chinantec villages are also numerous in the north-western part of the region. It must be noted, however, that although most serranos, as they are sometimes called, consider themselves Zapotec (or Chinantec), the indigenous languages are no longer spoken in many villages. Some villages of the region are relatively affluent, including Capulálpam, my research base, but most communities suffer from extreme poverty and the lack of most basic infrastructure, and have in 
recent decades faced various socio-economic challenges, such as the decline of traditional subsistence activities, the increase of inequality, unemployment, violence, and out-migration. Because of the latter, some communities have become veritable ghost villages (pueblos fantasmas), as they are sometimes called, surviving only on the remittances sent by men who have migrated to bigger cities and to the United States.

The cultural and socio-political organisation of the indigenous villages of the Sierra Juárez is based on customary norms and traditions. In the local discourse, the phrase usos y costumbres ('habits and customs') is generally used as a cover term to denote various civil (e.g. the hierarchical system of cargos or positions in the organisational structure of the villages that all men have to periodically hold, local forms of decision making, customary norms, collective communal work) and religious practices (e.g. Catholic fiestas and other rituals, as well as cargos with the Catholic Church). Usos y costumbres are considered 'autochthonous' by most villagers and as such they constitute a strong basis for collective identity and solidarity. Their legitimacy stems from the perception that usos y costumbres embrace native practices and values inherited from the past generations. "Here custom is law (Aquí la costumbre es la ley)," I was often told by my informants.

In reality, however, customary norms and social organisation of the villages can be quite contested. The rules pertaining to the realm of customary law are perceived differently by different people and social groups. Protestants, for example, often vocally criticise the obligatory nature of participating in collective communal and especially Catholic practices. Women often lament their lack of access to decision-making processes. Many others regard the social organisation based on customary norms as repressive and undemocratic rather than 'social glue', which ties villagers together. A common saying in the Sierra Juárez Pueblo pequeño, infierno grande ('Small village, big hell') - neatly captures the tensions embedded in such communal way of living.

Despite the contested nature of usos y costumbres, it could nevertheless be argued that la comunidad ('community') constitutes a fundamental political and social unit in the Sierra Juárez. Strong communal affiliation constitutes the main basis for collective identity in most villages. Various studies have eloquently demonstrated that people strongly identify themselves with the community as a place and as a corporate social entity in the Sierra Juárez (e.g. Kearney 1971; De la Fuente 1977; Alatorre Frenk 1998) as well as elsewhere in Oaxaca (Barabas 1998; Mendoza Zuany 2008). Nader (1990: 3) in her wellknown account of Zapotec dispute settlements in the village of Talea similarly suggests that the ideologies of harmony and solidarity are deeply embedded in the social organisation and mentality of contemporary Zapotec villages. 
One important and from the point of view of this paper relevant outcome of such strong identification with the community as a collective whole is the fact that the political and cultural calendar of most villages in the Sierra Juárez is full of social events that engage large groups of people on a regular basis. Consuming alcohol, especially mezcal, is part and parcel of these events. But it is not the act of drinking as such, but rather how mezcal is locally perceived and talked about, and what role it is endowed with in personal and collective well-being, that constitute anthropologically the most interesting aspects of the drink. In a classic article entitled On Key Symbols, Sherry Ortner (1973: 1339) distinguishes between two types of key symbols: summarising and elaborating ones. The former "are those symbols which are seen as summing up, expressing, representing for the participants in an emotionally powerful and relatively undifferentiated way, what the system means to them" (Ortner 1973: 1339). The latter "work in the opposite direction, providing vehicles for sorting out complex and undifferentiated feelings and ideas, making them comprehensible to oneself, communicable to others, and translatable into orderly action" (ibid.: 1340).

When carefully scrutinising the local discourse on mezcal, Ortner's concept of a summarising symbol appears to be highly fitting and appropriate. According to my experience in the Sierra Juárez, the word 'mezcal' is locally often used as a metaphor, rather than a simple signifier, standing for the alleged essence of the indigenous population or a person. It is not uncommon to talk of somebody being 'as strong as mezcal' or having 'mezcal's character'. Mezcal is talked about and treated with reverence, it is often personified, and endowed with a particular 'personality' that is somewhat congruent with that of the rural population. Mezcal's smoky flavour and its acutely strong taste, for example, are considered to stand for the toughness, sturdiness, and resilience of the people living in harsh mountain conditions. As one of my informants - Javier, a middle-aged peasant - eloquently claimed:

We, the Zapotecs of the Sierra, are strong and tough like mezcal. We do not get sick, we do not give up because we have mezcal. It is like the blood in our veins.

Mezcal is also endowed with nearly miraculous curative powers. A common saying attributed to this drink in all of Oaxaca - Para todo mal, mezcal, y para todo bien también ('for everything bad, mezcal, and for everything good, too') neatly summarises the perceived 'multifunctionality' of the beverage. Mezcal is widely considered to be an appropriate cure in almost any circumstances. It is believed to help control various illnesses, such as hypertension and diabetes, and it is even considered an aphrodisiac. Traditional curanderas ('healers') 
often use mezcal to cure folk illnesses, such as susto (fright sickness), empacho (digestive disorders of various kinds), and mal de ojo (evil eye). Even when catching a common cold or a fever, local people would in the first instance rely on a shot of mezcal mixed with salt and lemon, rather than on Western medicine. To sum up, mezcal thus expresses and represents "in an emotionally powerful and relatively undifferentiated way", to reiterate Ortner's words, the social and physical reality of the Sierra Juárez and that of the serranos.

\section{DRINKING MEZCAL AS A 'SOCIAL GLUE'}

Offering mezcal during religious and other festivities constitutes the prime indication of hospitality and almost a moral responsibility. Mezcal is strongly associated with the obligation to share but also to receive: accepting the drink is as strong a moral obligation as offering it. During popular rituals, for example, when religious processions pass the 'sponsoring' households of a particular fiesta, the hosts would offer mezcal in small plastic cups on trays to hundreds or even more participants. ${ }^{15}$ On less formal occasions, the drinkers (mainly men) would gather around the bottle and consume mezcal together in rounds of shots. On such occasions, it is seldom appropriate to accept one shot only. A common saying in Mexico, "Uno, no es ninguno; dos es la mitad de uno; y tres es apenas uno" ('one is nothing, two is half of one, and three is barely one'), is widely cited when one tries to reject yet another shot. Nor is it considered appropriate to drop out of the circle of collective drinking before others. "El último es cuando te vas al panteón" ('the last one is when you go to the cemetery') is another common pun often used if one wants to quit the group of drinkers. The drinking of mezcal often also involves various small rituals such as spilling some drops from the glass onto the ground as an offering to the fertility of the earth. Before drinking the first shot, one commonly says, "Arriba, abajo, al centro y pa'dentro" ("up, down, centre and in'). Mezcal-filled cups are commonly put on home altars during the Day of the Dead, as well as on tombs of the deceased relatives.

The nearly ritualised drinking of mezcal functions as a social glue, primarily among men. In anthropological research on food, scholars have extensively studied eating in ritual contexts and demonstrated how it can reaffirm social relationships (e.g. Munn 1986; Buitelaar 1993; Feeley-Harnik 1995; Brown 1995). For example, rituals and beliefs surrounding food have been shown to reinforce religious and ethnic boundaries, (e.g. Bahloul 1989; Fabre-Vassas 1997). As Mintz and Du Bois (2002: 109) argue, like all culturally defined material substances used in the creation and maintenance of social relationships, food serves both to solidify group membership and to set groups apart. All this can 
also be argued about alcohol, maybe even more convincingly so. The sharing of drinks can be a valuable way to build up social credit (e.g. Barlett 1980; Collmann 1979; Spradley 1970), or to institutionalise patron-client relationships (e.g. Jennings 2004). The drink that constitutes a potent cultural symbol does not necessarily need to be alcoholic, of course. For example, Pohjola (2008) shows in her study of symbolic and social dimensions of drinking mate in Argentina that this drink is associated with strong moral responsibility to share, and constitutes a key symbol of 'Argentinianness' in much the same way as mezcal in rural Oaxaca. Mate symbolises above all sociality, solidarity, equality, friendship, and communality. A comparable example would be the Japanese tea-ceremony ( $c h a d \bar{o})$. Furthermore, alcohol is obviously not the only psychoactive substance, the sharing of which has solidarity-enhancing effects. Allen (1988), for example, has demonstrated how the collective chewing of coca-leaves in the Peruvian Andes contributes to increasing and maintaining group solidarity. The collective use of various drugs in the West has also been analysed as a social ritual (e.g. Grund 1993).

From an anthropological perspective, the positive impact of consuming mezcal on group solidarity in rural Oaxaca is most apparent when scrutinising men's behaviour in nearly 'institutionalised' drinking settings. One among such in the Oaxacan villages is the collective drinking after asamblea comunal (communal assemblies), periodically organised meetings of all (male) members of the community. All decisions concerning the community as a corporate entity in the Sierra Juárez are ideally made during these meetings, because they have maximal power in communal life (Durand Alcántara 1998: 273). One can regard communal assemblies not just as mechanisms that create communal unity by producing collective decisions, but also as the moments of 'social catharsis' akin to Gluckman's (1963) 'rituals of rebellion'. Direct and explicit criticism in face-to-face communities can be dysfunctional. Communal assembly, however, is the legitimate context for expressing discontent and challenging the village authorities, because in this framework criticism serves communal well-being and loses much of its personal nature. Communal assembly is an example of Turner's (1974 [1969]) communitas - ideally everybody present has the right to speak, criticise, and express their opinion, everybody's voice has equal weight, and the hierarchy of the cargo system is forgotten. Often resulting in heated arguments and confrontations, the aim is generally to resolve these among the villagers themselves, within the temporal and spatial confines of the assembly. As one of my informants explained, "Although we fight, we fight amongst ourselves and amongst ourselves it stays."

In reality, however, tensions surfacing during the assemblies do not remain confined to the assembly hall. To alleviate the resentment and negativity that 
accumulates during these encounters, most men, after the end of the assembly, tend to go to cantinas (bars) to wind down and drink mezcal. It is this collective drinking rather than the communal assembly that has a truly cathartic impact on social relations. Going to a cantina or accepting others' invitation is a strong moral obligation. "This is the only entertainment we have here to alleviate stress and tensions, and to resolve conflicts," as Pedro, a middle-aged informant, rather bluntly put it.

This is not to say, however, that all men in the villages of the Sierra Juárez drink mezcal or alcohol more generally. To return to the idea by Mintz and Du Bois (2002: 109) cited above, culturally defined substances not only solidify group membership, but they can also set groups apart. Consuming alcohol and rejecting it largely coincides with the religious divide between Catholics and Protestants in the villages. Like most of Latin America, Mexico, especially its rural areas, has in recent decades experienced an unprecedented rise of Protestant churches. One of the important social features of Protestant converts, alongside with the break with local customs, is their absolutist abstention from alcohol. In fact, consumption of alcohol becomes for Protestants a major defining feature of Catholics as a group, a characteristic as important as the Catholics' veneration of saints and images. "The Catholics like drinking, we like God," as María, a young Pentecostal woman, summarised what, according to her, was the main difference between her faith and that of Catholics. The fact that alcohol can serve as highly charged focus of symbolic contestation in identity struggles between Protestants and Catholics has also been demonstrated in other ethnographic contexts (e.g. Luning 2002). Protestants would often group the drinking of mezcal together with various other sins that Catholics are held responsible for, and the consumption of alcohol is talked about exclusively in terms of alcohol abuse. Fabio, a Jehovah's Witness, put it accordingly:

Here people are very Catholic and that is why many dirty things existfornication, adultery, drunkenness. Thirty percent of the population here are alcoholics, both men and women.

An obvious conclusion to be drawn from the existence of such a religious divide in attitudes towards alcohol is that the symbolic and social meanings of mezcal described above are not shared by everyone. For Protestant converts, mezcal has become a negative symbol of sorts. As Dietler (2006: 241) also argues when analysing the links between alcohol and religion, abstention from drinking can, for some religions, become one of the most important defining symbols of piety and group membership. It would perhaps be an exaggeration to claim that abstinence stands for a summarising symbol for Protestants in the Sierra 
Juárez, but it has clearly become an integral part of Protestant identity in a Catholic village.

There is additional important dimension to Protestants' critique of drinking that is related to the converts' particular life-histories. Many Protestant converts are in fact former alcoholics for whom conversion to Protestantism has constituted a means for quitting the vice. Dennis (1975) and Kearney (1991) have also demonstrated that religious conversion can be consciously and purposefully used as an escape strategy from the almost 'institutionalised' obligation to drink in the Oaxacan villages. For example, in Ixtepeji, a village characterised by a 'culture of alcoholism' according to Kearney (1991: 349), most male Adventists had been heavy drinkers before converting. Hence the Protestants' critique of consuming alcohol is not only a religious discourse, but often also stems from a personal struggle of breaking with one's past behaviour.

\section{FROM THE LOCAL TO THE NATIONAL: FINDING MEXICANNESS IN MEZCAL}

Much like pulque's image immediately after the Mexican revolution, the image of mezcal as a drink and as a symbol is currently undergoing significant changes. Recent state and national level efforts to commercialise the production of mezcal, turn it into a touristic curiosity ${ }^{16}$, and market the drink aggressively, both in Mexico and abroad, have facilitated its slow transformation from a beverage with a predominantly local appeal into a 'national drink', which is being produced increasingly for export and for tourists (see, e.g., De Barrios 2002 [1971]).

Owing to these efforts, the mezcal industry in Mexico and especially in Oaxaca has evolved into an economic sector of its own, which according to some estimates (DGAPEAS 2011: 3) generates at least 29,000 jobs. Morales Carillo, Escobar Moreno, and Paredes Hernández (2007: 9-14) divide mezcal producers in contemporary Mexico into three groups: small producers still using traditional technology and methods, family-run palenques with traditional methods but more modern technology, and big factories with large productive capacity. The second group is by far the most numerous, but also the most vulnerable to the potential adverse effects of aggressive commercialisation. Most notably, the success of the mezcal industry has also led to increased control mechanisms and standardisation. As the production of mezcal for export has grown - the produced volume grew by 300 percent in 2005-2009, amounting to 1.8 million litres (DGAPEAS 2011: 3) - so have the regulations on production become more severe. The Regulating Mexican Council of the Quality of the Mezcal (COMERCAM) is a special institution that now certifies mezcal 
brands and monitors their compliance with the standard called NOM-070SCFI-1994 (Bautista \& Terán Melchor 2008). Such rigorous standardisation is understandable but can have repercussions, especially for small producers, who often lack the economic resources and also the knowledge to comply with the regulations (Morales Carillo \& Escobar Moreno \& Paredes Hernández 2007). Also, the fact that mezcal production is now increasingly controlled by middlemen, including governmental bodies, means that it can be affected by political factors and local power structures (Bautista et al. 2007; Bautista \& Terán Melchor 2008). Another challenging and controversial issue is taxation. In recent years, the sector has suffered from increasing taxation burden that can amount to 69 percent (Proceso 2002; Zavala 2013). Again, this has hit the small producers particularly hard.

Despite these challenging developments, the mezcal industry has been a blessing for Oaxaca. The state produces more than half of Mexican mezcal and there are at least 500 small producers in Oaxaca alone (Mendoza Escamilla 2012). The production of the drink has turned into a much-needed source of employment for the otherwise marginalised regions and families, and the mezcal industry now constitutes one of the biggest sources of income in Oaxaca alongside tourism. According to DGAPEAS (2011: 3), in 2009 mezcal industry generated 6.5 percent of the total income of Oaxaca, only slightly less than produced by beer $(8.7 \%)$ and tequila $(7.1 \%)$.

The skilful blending of mezcal and tourism - Oaxaca's main sector of incomeis particularly interesting. The increasingly popular 'mezcal tours' organised by many travel agencies and the yearly held International Mezcal Festival (Feria Internacional del Mezcal) in Oaxaca City are indications of this. The latter event is sponsored by the state government of Oaxaca and was begun in 1997, not coincidentally to accompany the Guelaguetza festival, which is the biggest state-sponsored cultural event in Oaxaca held yearly in the last two weeks of July. Besides conventional mezcal tasting and the promotion of different brands, the festival events also include the coronation of the Queen of Mezcal, traditional dances, and folkloric events aiming to associate mezcal closely with Oaxacan folk culture. The Mexican Ministry of Tourism and Economic Development is currently making plans to launch in Oaxaca the so-called mezcal-route, building on the Ministry's previous experience of the hugely popular 'tequila route' in Jalisco (Enfoque Oaxaca 2011). Mezcal-related literature for the local readership as well as for tourists is also proliferating rapidly (e.g. Arellanes Meixuiero 1997; Torrentera 2001, 2004, 2009; De Gortari \& Escamilla 2009).

Torrentera (2001) uses the term 'mezcalaria' to denote this recent zeal to promote and reinvent the image of mezcal as a drink of great appeal and 'profound character'. Interestingly, although not surprisingly, some aspects of the local 
level metaphorical discourse of mezcal discussed above are being reproduced at the state and national level. The familiar notions of character, magic, and authenticity, as well as the references to mezcal's curative qualities are very much present in the current official discourse on mezcal. To bring just a few examples from the 'mezcal-literature', De Gortari and Escamilla (2009) call mezcal 'our essence' and try to delineate the putative 'magic world of mezcal'. Arellanes Meixuiero (1997) suggests that mezcal is the 'elixir of long life' and Blomberg (2000) considers mezcal (together with tequila and pulque) as the metaphor of lo auténtico mexicano ('Mexican authenticity').

\section{CONCLUSIONS}

This paper has scrutinised mezcal and its consumption from the 'constructive' perspective. I have studied mezcal as a cultural category and endeavoured to demonstrate that this drink constitutes a symbolically potent metaphor in the rural areas of Oaxaca. It could be concluded that the symbolic discourse about mezcal in indigenous Oaxacan communities is essentially a cultural discourse about 'the self'. I have also argued that offering, sharing, and accepting mezcal has moral connotations, and that its consumption has an important social dimension - collective drinking occasions unite men. But consuming mezcal also marks a boundary between different social groups: women, although this is no longer always the case, as well as Protestants generally abstain from drinking mezcal. Such symbolic and social dimensions of mezcal are not necessarily manifest for an outsider, but here lies the contribution of anthropological analysis. Putting emphasis on emic perspectives and taking the native's point of view, anthropology enables us to uncover these implicit meanings.

In other words, from the anthropologist's perspective, drinking mezcal in an Oaxacan village constitutes an act that is culturally much more complex and meaningful than a 'simple' practice of consuming alcohol. Drinking mezcal is, among other things, a symbolic act. Naturally, making a symbolic statement does not need to (although it may) be a conscious intention from the part of the drinker. And yet, the act of such drinking inevitably signals to the rest of the community the drinker's belonging or not belonging to a certain social circle or a (sub)cultural group. It redraws a moral boundary between different individuals, or, possibly, undraws the previously existing one. For example, one can conclude with considerable certainty that the person drinking mezcal is not a Protestant. Yet it is not so much the association of mezcal with alcoholism that leads to Protestants' abstentionism but rather linking it to fiestas and saints - hence to religious idolatry. Similarly, the fact that one can now 
witness considerably more women sipping mezcal during various social occasions, can be explained by the symbolic connotations of the drink rather than by women's emancipation in the villages traditionally characterised by rather patriarchal social and value structures. Consuming mezcal, the autochonous and nearly sacred beverage, is less frowned at by men than women drinking other alcoholic drinks, including beer. Moreover, drinking mezcal has become for many - men and women alike - a way of emphasising one's indigenousness, which in turn increases the drink's exotic appeal for tourists.

The idea that there is a connection between collective identities, food, and drinks, is anthropologically not novel of course. Nor is it surprising that certain cultural categories or images can acquire the role of what Ortner (1973) calls the 'key symbols'. In the case of Mexico and Mexicanness in particular, anthropologists have for long undertaken such symbolic analysis. Already more than half a century ago Eric Wolf (1958) described the Virgin of Guadalupe as Mexico's 'master symbol', which captures the mesticised essence of Mexicans and the Mexican culture. What makes the case of mezcal as a symbol particularly interesting, however, is the fact that one can literally observe its symbolic transformation at this very moment. Although mezcal has always been in the shadow of tequila and pulque, this to date mainly locally produced and consumed beverage is now being constructed as a national drink. Mezcal's novel and culturally constituted relationship with Mexicanness builds on its local symbolic and social connotations that I have outlined in this article.

\section{NOTES}

1 This research was supported by the European Union through the European Regional Development Fund (Center of Excellence CECT), and the Estonian Science Foundation (grant ETF8335).

2 I first arrived in Oaxaca in August 1998, as a visiting doctoral researcher at the Centre of Advanced Study and Research in Social Anthropology (Centro de Investigaciones $y$ Estudios Superiores en Antropología Social or CIESAS). Eighteen months of continuous fieldwork in the Zapotec region called the Sierra Juárez produced empirical data gathered from altogether 39 communities. During this and later stretches of fieldwork, the village of Capulálpam de Méndez has served as the base of my research, from where I have made countless visits to other villages. After my doctoral fieldwork, I returned to Oaxaca and the Sierra Juárez on four occasions, most recently in 2012. These fieldwork periods lasted from three to four weeks. Naturally, over the period of more than a decade, my research themes have been multiple. Symbolic and social connotations of mezcal is but one of the numerous topics I have scrutinised in the Sierra Juárez, and my other foci of interest have ranged from Protestant conversion and religious conflicts to anthropology of tourism and customary law. The data gathered over the period of 15 years includes notes based on participant observation in daily 
communal life and many ritual and festive occasions, transcripts of innumerable informal conversations, more than 150 unstructured and narrative interviews with individuals from various villages, three statistical surveys, archival materials in the State Archive of Oaxaca and the General Archive of the Nation in Mexico City, content analysis of the articles on various topics in the 1988-2010 issues of Noticias (a major Oaxacan newspaper), and Mexican CENSUS data. The discussion in this paper is based on empirical data from all fieldwork stages, as well as 12 more targeted interviews during my last fieldwork in Oaxaca in 2012.

3 Extensive overviews of anthropological perspectives on alcohol can be found in Heath (1987) and Dietler (2006).

${ }^{4}$ In 1965, Mandelbaum published a path-breaking article, in which he summarised some of the key issues for anthropologists in the study of alcohol. In another early study, MacAndrew and Edgerton (1969) combined ethnographic and ethno-historical evidence to demonstrate that drunken behaviour, although undoubtedly affected by biochemical and neuropharmacological factors, is also a product of culture-specific expectations and values.

5 Mendieta y Núñez (1939) even estimated that, in the 1930 s, up to 60 percent of the indigenous population in Mexico was drunk daily. In a more recent account on alcohol abuse in Mexico, Borges et al. (2007) suggest that alcohol consumption alone accounts for nine percent of the total burden of illness in Mexico. The proportion of alcohol-attributable deaths in Mexico is among the highest in the Americas (Rehm et al. 2006).

${ }^{6}$ Pulque is one of the 'archetypal' drinks of Mexico, which will be discussed in more detail below.

7 The beverage was allegedly first produced in the 16th century near the city of Tequila, which gave it its name. Mexico has claimed exclusive rights to the production of tequila, and its production is limited to the state of Jalisco and selected regions in Guanajuato, Michoacán, Nayarit, and Tamaulipas (e.g. Blomberg 2000).

8 The original name of the drink in Nahuatl was iztac octli ('white wine'). The term pulque was probably mistakenly derived by the Spanish from the octli poliuhqui meaning 'spoiled wine' (Gaytán 2007: 3).

9 In colonial villages, pulque was particularly associated with two prominent Mexican festivals: the Day of the Dead and the fiesta for the Virgin of Guadalupe (Taylor 1979: $58)$.

${ }^{10}$ Pulque was, for example, Frida Kahlo's favourite drink. For her it epitomised the sense of Mexican national identity fostered in the post-revolutionary period (Wright 2009). Kahlo's husband, the muralist Diego Rivera, often depicted pulque and pulquerías in his paintings to symbolically incorporate workers and indigenous communities two groups mainly associated with pulque production and consumption - within the discourse of Mexicanness (Wright 2009: 3). On the depictions of pulque in Mexican fine arts and literature, see also Ramírez Rodríguez (2007) and Olea Franco (2010).

${ }^{11}$ Pulque is nowadays mostly consumed in the central highlands. Not surprisingly, its consumption is mainly associated with poverty. 
12 There are two basic types of mezcal: one is made of 100 percent maguey and the other is a mix of different ingredients, with at least 60 percent maguey. But the actual subtypes can be highly varied, depending on the subspecies of agave used, and the fruits and herbs added during the fermentation and distillation processes. Some mezcals, usually from the state of Oaxaca, are famously sold con gusano ('with a worm'). This worm, added during the bottling process, is the larval form of the moth Hypopta agavis that lives on the agave plant (see, e.g., Torrentera 2009).

${ }^{13}$ In the production process, the extracted piñas, or hearts of the harvested plants, are cooked for a number of days in pit ovens, then crushed and mashed, and left to ferment. The resulting liquid is distilled and left to age for between one month and four years, sometimes even longer. Mezcal can reach an alcohol content of 55 percent. An interested reader may consult Torrentera (2001, 2004, 2009) for more detailed descriptions of the production of mezcal.

14 The overwhelming majority of Mexican mezcal production is concentrated in Oaxaca, although some well-known mezcals also come from other states, such as Guerrero. Oaxaca, the acknowledged mezcal region, comprises seven districts in the Central Valley, covering altogether about one million hectares (Bautista and Terán Melchor 2008: 113).

15 The most populous processions of such kind take place in indigenous villages of Oaxaca during Easter and the fiesta of the village patron saint.

${ }^{16}$ Mezcal's exotic appeal is often cultivated with rather explicit means. Although the worm (gusano) put in the bottle of some mezcals is considered to add flavour to the drink and serve as a proof that mezcal is fit to drink, many claim that it is merely a marketing ploy (e.g. Asimov 2010). To catch even further attention, some producers, like Caballeros, have introduced what they call 'Scorpion mezcal', with an intact scorpion added to the drink.

\section{MANUSCRIPT SOURCES}

Fieldwork materials from the years 1998-2012 in possession of the author.

\section{REFERENCES}

Alatorre Frenk, Gerardo 1998. La empresa social forestal y sus asesores: avances y dificultades en la construcción de la democracia, la eficiencia y la sustentabilidad. Doctoral thesis in anthropology. México, D.F.: UNAM.

Allen, Catherine J. 1988. The Hold Life Has: Coca and Cultural Identity in an Andean Community. Washington: Smithsonian Institution Press.

Arellanes Meixuiero, Anselmo 1997. Mezcal: elixir de larga vida. México, D.F.: C.V.S. Publicaciones. 
Asimov, Eric 2010. Mezcal, Tequila's Smoky, Spicy Cousin. The New York Times, August 16, 2010. Available at http://www.nytimes.com/2010/08/18/dining/ reviews/18wine.html?pagewanted=all\&_r=0, last accessed on October 7, 2014.

Avila Palafox, Ricardo 2001. Cantinas and Drinkers in Mexico. In: Igor de Garine \& Valerie de Garine (eds.) Drinking: Anthropological Approaches. New York: Berghahn Books, pp. 169-180.

Bahloul, Joelle 1989. From a Muslim Banquet to a Jewish Seder: Foodways and Ethnicity among North African Jews. In: Mark R. Cohen \& Abraham L. Udovitch (eds.) Jews Among Arabs: Contacts and Boundaries. Princeton: Darwin Press, pp. 85-95.

Barabas, Alicia M. 1998. Reorganización etnopolítica y territorial: caminos oaxaqueños para la autonomía. In: Miguel A. Bartolomé \& Alicia M. Barabas (eds.) Autonomías étnicas y estados nacionales. México, D.F.: INAH, pp. 343-366.

Barlett, Peggy F. 1980. Reciprocity and the San Juan Fiesta. Journal of Anthropological Research, Vol. 36, No. 1, pp. 116-130.

Barrows, Susanna \& Room, Robin (eds.) 1991. Drinking: Behavior and Belief in Modern History. Berkeley: University of California Press.

Bautista, Juan Antonio \& Ramirez Juárez, Javier \& Martínez Corona, Beatriz \& Peña Olvera, Benjamín \& Martínez Saldaña, Tomás 2007. El Sistema de usos y costumbres bajo el poder económico y politico local en el municipio de Matatlán, Oaxaca. In: Jorge Hernández-Díaz (ed.) Ciudadanías diferenciadas en un estado multicultural: Los usos y costumbres en Oaxaca. Mexico City: Siglo XXI, UABJO, pp. 131-150.

Bautista, Juan Antonio \& Terán Melchor, Edit 2008. Estrategias de producción y mercadotecnia del mezcal en Oaxaca. El Cotidiano, Vol. 23, No. 148, pp. 113-121. Available at http://www.elcotidianoenlinea.com.mx/pdf/14811.pdf, last accessed on October 7, 2014.

Blomberg, Lennart 2000. Tequila, mezcal y pulque: lo auténtico mexicano. México, D.F.: Editorial Diana.

Borges, Guilherme \& Medina-Mora, María Elena \& Lara, Carmen \& Zambrano, Joaquin \& Benjet, Corina \& Fleiss, Clara 2007. Alcohol Use and Alcohol Use Disorders in Mexico. Contemporary Drug Problems, Vol. 34, No. 3, pp. 389-410.

Brown, Karen McCarthy 1995. Serving the Spirits: The Ritual Economy of Haitian Vodou. In: Donald J. Cosentino (ed.) Sacred Arts of Haitian Vodou. Los Angeles: UCLA Fowler Museum of Cultural History, pp. 226-239.

Bruman, Henry J. 2000. Alcohol in Ancient Mexico. Salt Lake City: University of Utah Press.

Buitelaar, Marjo 1993. Fasting and Feasting in Morocco: Women's Participation in Ramadan. Oxford: Berg.

Bunzel, Ruth 1940. The Role of Alcoholism in Two Central American Cultures. Psychiatry: Journal for the Study of Interpersonal Processes, Vol. 3, pp. 361-387.

Collmann, Jeff 1979. Social Order and the Exchange of Liquor: A Theory of Drinking among Australian Aborigines. Journal of Anthropological Research, Vol. 35, No. 2, pp. 208-224.

De Barrios, Virginia B. 2002 [1971]. A Guide to Tequila, Mezcal and Pulque. Mexico City: Minutiae Mexicana S.A de C.V. 
De Gortari, Yuri \& Escamilla, Edmundo 2009. Mezcal, nuestra esencia. México, D.F.: Ámbar Diseño.

De la Fuente, Julio 1977. Yalálag: una villa zapoteca serrana. México, D.F.: INI.

Dennis, Philip A. 1975. The Role of the Drunk in a Oaxacan Village. American Anthropologist, Vol. 77, No. 4, pp. 856-863. http://dx.doi.org/10.1525/aa.1975.77.4.02a00080.

DeWalt, Billie R. 1979. Modernization in a Mexican Ejido: A Study in Economic Adaptation. Cambridge: Cambridge University Press.

DGAPEAS 2011. Monografía del Mezcal. Mexico City: Dirección General Adjunta de Planeación Estratégica y Análisis Sectorial. Available at http://www. financierarural.gob.mx/informacionsectorrural/Documents/Monografias/ MonografiaMezcal\%28mar11\%29.pdf, last accessed on October 7, 2014.

Diaz Montes, Fausto 1982. La producción de mezcal en Oaxaca. In: Raúl Benítez Centeno (ed.) Sociedad y política en Oaxaca 1980: 15 estudios de caso. Oaxaca: Instituto de Investigaciones Sociológicas, UABJO, pp. 59-82.

Dietler, Michael 2006. Alcohol: Anthropological/Archaeological Perspectives. Annual Review of Anthropology, Vol. 35, pp. 229-249. http://dx.doi.org/10.1146/annurev. anthro.35.081705.123120.

Douglas, Mary (ed.) 1987. Constructive Drinking: Perspectives on Drink from Anthropology. Cambridge: Cambridge University Press.

Durand Alcántara, Carlos H. 1998. Derecho nacional, derechos indios y derecho consuetudinario indígena: los triquis de Oaxaca, un estudio de caso. Texcoco: Universidad Autónoma Chapingo.

Eber, Christine E. 1995. Women and Alcohol in a Highland Maya Town: Water of Hope, Water of Sorrow. Austin: University of Texas Press.

Elvridge-Thomas, Roxana 2009. De moles, pulques, dulces y bisteces: La comida en la ciudad de México durante el siglo XIX. Fuentes Humanísticas, Vol. 38, pp. 59-70. Available at http://fuenteshumanisticas.azc.uam.mx/revistas/38/Fuentes38.pdf, last accessed on October 7, 2014.

Enfoque Oaxaca 2011. Promueven "Ruta del Mezcal" para Oaxaca. Available at http://enfoqueoaxaca.com/aqui-y-ahora2/promueven-\%E2\%80\%98ruta-delmezcal\%E2\%80\%99-para-oaxaca/, last accessed on October 10, 2014.

Fabre-Vassas, Claudine 1997. The Singular Beast: Jews, Christians, and the Pig. New York: Columbia University Press.

Feeley-Harnik, Gillian 1995. Religion and Food: An Anthropological Perspective. Journal of the American Academy of Religion, Vol. 63, No. 3, pp. 565-582. doi:10.1093/ jaarel/LXIII.3.565.

Garine, Igor de \& Garine, Valerie de 2001. Drinking: Anthropological Approaches. New York: Berghahn Books.

Gaytán, Marie S. 2007. Fermented Struggles and Distilled Identities: How Tequila Became Mexico's Spirit. Available at http://citation.allacademic.com/meta/p_ mla_apa_research_citation/1/8/2/8/3/pages182832/p182832-1.php, last accessed on October 7, 2014.

Gefou-Madianou, Dimitra (ed.) 1992. Alcohol, Gender, and Culture. London: Routledge. Gluckman, Max 1963. Rituals of Rebellion in South East Africa. In: Max Gluckman. Order and Rebellion in Tribal Africa. London: Cohen and West, pp. 110-136. 
Grant, Marcus \& Litvak, Jorge (eds.) 1997. Drinking Patterns and Their Consequences. Washington: Taylor \& Francis.

Grund, Jean-Paul C. 1993. Drug Use as a Social Ritual: Functionality, Symbolism and Determinants of Self-Regulation. Rotterdam: Instituut voor Verslavingsonderzoek. Available at http://www.drugtext.org/pdf/grund01.pdf, last accessed on October 7, 2014.

Guerrero Guerrero, Raúl 1985. El pulque. México, D.F.: INAH.

Heath, Dwight B. 1987. Anthropology and Alcohol Studies: Current Issues. Annual Review of Anthropology, Vol. 16, pp. 99-120. http://dx.doi.org/10.1146/annurev. an.16.100187.000531.

Heath, Dwight B. 1995. International Handbook on Alcohol and Culture. Westport: Greenwood Publishing Group.

Heath, Dwight B. 2000. Drinking Occasions: Comparative Perspectives on Alcohol and Culture. Philadelphia: Taylor and Francis.

Hobsbawm, Eric \& Ranger, Terence (eds.) 1983. The Invention of Tradition. Cambridge: Cambridge University Press.

Jennings, Justin 2004. La Chichera y el Patrón: Chicha and the Energetics of Feasting in the Prehistoric Andes. Archaeological Papers of the American Anthropological Association, Vol. 14, pp. 241-259. http://dx.doi.org/10.1525/ap3a.2004.14.241.

Kearney, Michael 1970. Drunkenness and Religious Conversion in a Mexican Village. Quarterly Journal of Studies on Alcohol, Vol. 31, No. 1, pp. 132-152.

Kearney, Michael 1971. Los vientos de Ixtepeji. México, D.F.: Instituto Indigenista Interamericano.

Kearney, Michael 1991. Borrachera y conversión religiosa en un pueblo mexicano. In: Eduardo L. Menéndez (ed.) Antropología del alcoholismo en México: los límites culturales de la economía política (1930-1979). México, D.F.: CIESAS, pp. 329-351.

Luning, Sabine 2002. To Drink or Not to Drink: Beer Brewing, Rituals, and Religious Conversion in Maane, Burkina Faso. In: Deborah F. Bryceson (ed.) Alcohol in Africa: Mixing Business, Pleasure, and Politics. Portsmouth, N.H.: Heinemann, pp. 231-248.

MacAndrew, Craig \& Edgerton, Robert B. 1969. Drunken Comportment: A Social Explanation. Chicago: Aldine.

Mallery, Garrick 1888. Manners and Meals. American Anthropologist, Vol. 1, No. 3, pp. 193-207. doi: 10.1525/aa.1888.1.3.02a00000.

Mandelbaum, David G. 1965. Alcohol and Culture. Current Anthropology, Vol. 6, No. 3, pp. 281-294. http://dx.doi.org/10.1086/200597.

Marshall, Mac (ed.) 1979. Beliefs, Behaviors, \& Alcoholic Beverages: A Cross-Cultural Survey. Ann Arbor: University of Michigan Press.

Marshall, Mac 1990. "Problem Deflation" and the Ethnographic Record: Interpretation and Introspection in Anthropological Studies of Alcohol. Journal of Substance Abuse, Vol. 2, No. 3, pp. 353-367. http://dx.doi.org/10.1016/S0899-3289(10)80007-0.

Mendieta y Núñez, Lucio 1939. Ensayo sobre el alcoholismo entre las razas indígenas de México. Revista Mexicana de Sociología, Vol. 1, pp. 77-93.

Mendoza Escamilla, Viridiana 2012. El mezcal, 'cuna' de nuevos exportadores. CNNExpansion. Available at http://www.cnnexpansion.com/emprendedores/2012/02/24/ una-bebida-de-dioses-y-emprendedores, last accessed on October 7, 2014. 
Mendoza Zuany, Rosa G. 2008. Dealing with Diversity in the Construction of Indigenous Autonomy in the Sierra Norte of Oaxaca. Bulletin of Latin American Research, Vol. 27, No. 3, pp. 351-367. http://dx.doi.org/10.1111/j.1470-9856.2008.00274.x.

Menéndez, Eduardo L. (ed.) 1991. Antropología del alcoholismo en México: los límites culturales de la economía política (1930-1979). México, D.F.: CIESAS.

Mintz, Sidney W. \& Du Bois, Christine 2002. The Anthropology of Food and Eating. Annual Review of Anthropology, Vol. 31, pp. 99-119. doi: 10.1146/annurev. anthro.32.032702.131011.

Mitchell, Tim 2004. Intoxicated Identities: Alcohol's Power in Mexican History and Culture. New York: Routledge.

Montero, Lariza 2011. Los Mezcólatras: La logia del mezcal. Este México, Vol. 9, pp. $104-$ 108.

Morales Carrillo, Nicolás \& Escobar Moreno, Dario A. \& Paredes Hernández, Efraín 2007. Estudio sobre el impacto que las modificaciones a la NOM-070 traeran a la industria del mezcal. Texcoco: Universidad Autónoma Chapingo-CRUCEN. Available at http://www.crupy-uach.org.mx/encuentro/img/experiencias/doc/033 66a1b4b97c0c65907400d8a143feb.pdf, last accessed on October 8, 2014.

Munn, Nancy D. 1986. The Fame of Gawa: A Symbolic Study of Value Transformation in a Massim (Papua New Guinea) Society. Cambridge: Cambridge University Press.

Nader, Laura 1990. Harmony Ideology: Justice and Control in a Zapotec Mountain Village. Stanford: Stanford University Press.

Olea Franco, Rafael 2010. De una singular leche alabastrina: el pulque en la literatura mexicana del siglo XIX. Literatura Mexicana, Vol. 21, No. 2, pp. 203-223. Available at http://www.iifilologicas.unam.mx/litermex/uploads/volumenes/ volumen-21-2/13.\%20Rafael\%20Olea.pdf, last accessed on October 8, 2014.

Ortner, Sherry B. 1973. On Key Symbols. American Anthropologist, Vol. 75, No. 5, pp. 1338-1346. http://dx.doi.org/10.1525/aa.1973.75.5.02a00100.

Pittman, David Joshua \& Raskin White, Helene (eds.) 1991. Society, Culture, and Drinking Patterns Reexamined. New Brunswick, N.J.: Rutgers Center of Alcohol Studies.

Pohjola, Johanna 2008. Poné la pava - laita pannu tulelle: mate-juoma symbolina Argentiinassa. [Poné la pava - Put the Kettle On: Mate as a Symbol in Argentina.] MA thesis. Helsinki: University of Helsinki, Department of Social and Cultural Anthropology.

Proceso 2002. Oaxaca: productores de mezcal se amparan contra nuevo impuesto. Available at http://www.proceso.com.mx/?p=239419, last accessed on October 6, 2014

Ramirez, Juan F. \& Sanchez-Marroquin, A. \& Alvarez, Mario M. \& Valyasevi, Ruud 2004. Industrialization of Mexican Pulque. In: Keith H. Steinkraus (ed.) Handbook of Indigenous Fermented Foods. New York: Marcel Dekker, pp. 547-586.

Ramírez Rodríguez, Rodolfo 2007. La representación popular del maguey y el pulque en las artes. Cuicuilco, Vol. 14, No. 39, pp. 115-149. Available at http://www.redalyc. org/pdf/351/35111319006.pdf, last accessed on October 8, 2014.

Rehm, Jürgen \& Patra, Jayadeep \& Baliunas, Dolly \& Popova, Svetlana \& Roerecke, Michael \& Taylor, Benjamin 2006. Mexico 2002. Report to the World Health Organization. 
Rojas Gonzalez, Francisco 1942. Estudio hístórico-etnográfico del alcoholismo entre los Indios de México. Revista Mexicana de Sociología, Vol. 4, No. 2, pp. 111-125.

Room, Robin 1984. Alcohol and Ethnography: A Case of Problem Deflation? Current Anthropology, Vol. 25, No. 2, pp. 169-191. http://dx.doi.org/10.1086/203107.

Scardaville, Michael C. 1980. Alcohol Abuse and Tavern Reform in Late Colonial Mexico City. The Hispanic American Historical Review, Vol. 60, No. 4, pp. 643-671. http:// dx.doi.org/10.2307/2513670.

Serra, Mari C. \& Lazcano A., Carlos 2010. The Drink Mescal: Its Origin and Ritual Uses. In: John E. Staller \& Michael Carrasco (eds.) Pre-Columbian Foodways. New York: Springer, pp. 137-156.

Smith, William Robertson 1889. Lectures on the Religion of the Semites. New York: Appleton. Available at https://archive.org/details/lecturesontherel00smituoft, last accessed on October 8, 2014.

Spradley, James P. 1970. You Owe Yourself a Drunk: An Ethnography of Urban Nomads. Boston: Little, Brown.

Taylor, William B. 1979. Drinking, Homicide, and Rebellion in Colonial Mexican Villages. Stanford: Stanford University Press.

Torrentera, Ulises 2001. Mezcalaria: cultura del mezcal. México, D.F.: El Farolito.

Torrentera, Ulises 2004. Miscella mezcalacea. México, D.F.: El Farolito.

Torrentera, Ulises 2009. Breve guía del mezcal: historia del mezcal en síntesis. México, D.F.: El Farolito.

Turner, Victor 1974 [1969]. The Ritual Process. Harmondsworth: Penguin Books.

Wilson, Thomas M. 2005. Drinking Cultures: Alcohol and Identity. Oxford: Berg.

Wolf, Eric R. 1958. The Virgin of Guadalupe: A Mexican National Symbol. The Journal of American Folklore, Vol. 71, No. 279, pp. 34-39. http://dx.doi.org/10.2307/537957.

Wright, Amie 2009. "La Bebida Nacional": Pulque and Mexicanidad, 1920-46. Canadian Journal of History, Vol. 44, No. 1, pp. 1-24. Available at http://utpjournalsreview. com/index.php/CJOH/issue/view/270, last accessed on October 8, 2014.

Zavala, Juan Carlos 2013. Carga fiscal, lastre de la industria del mezcal. Available at http://ipoaxaca.mx/extensions/components/content-component/article-categorylist/172-carga-fiscal-lastre-de-la-industria-del-mezcal, last accessed on October 10, 2014. 